\title{
Implementasi Model Pembelajaran Card Sort Pada Mata Pelajaran Akidah Akhlak Kelas IV MI Al-Islam Desa Pranggang Kecamatan Plosoklaten Kabupaten Kediri
}

\author{
Uswatun Hasanah, ${ }^{1}$ Siti Wahyuni ${ }^{2}$ \\ ${ }^{1}$ Pascasarjana Institut Agama Islam Tribakti Kediri, 2Institut Agama Islam Tribakti Kediri \\ ${ }^{1}$ uswatunhasanah09@gmail.com, 2yunilirboyo@gmail.com
}

\begin{abstract}
Learning by using card sort can be through the principle of apperception, the principle of motivation, the principle of self-employment and the principle of regular repetition. With card sort students are more motivated in learning so they are able to understand lessons and improve learning outcomes in accordance with the expected completeness standards. This research method is qualitative. As with the direction of qualitative research, the collected data is analyzed with the provision of intellectual weapons in the form of theory as presented in chapter II to obtain various interpretative descriptions in accordance with the rules of scientific research that are logical and rational. The results of this study are: (1) The application of the Card Sort Method to grade IV students in akidah akhak subjects in MI Al-Islam Desa Pranggang Kecamatan Plosoklaten Kabupaten Kediri, the teacher gives an index card containing the material of moral study. The more students there are, the more card pairs there are. (2) Changes in student learning outcomes after being taught using class IV card sort method in akidah akhlak subjects in MI AlIslam Desa Pranggang Kecamatan Plosoklaten Kabupaten Kediri, are the cognitive test results of students getting an average score of 84.14 , on the affective aspects of students have a sense of faith and devotion to God in psychomotor students implementing Islamic religious teachings in daily life so as to shape the knowledge, attitudes and skills of all students here according to the target, which is to integrate the cognitive, affective and psychomotor domains in all learning activities. And the students' response to this learning method is very good because of students like the method of learning card sort
\end{abstract}

Keywords: Learning Card Sort, Akidah Akhlak

\begin{abstract}
Abstrak
Pembelajaran dengan menggunakan card sort dapat melalui asas apersepsi, asas motivasi, asas bekerja sendiri dan asas ulangan yang teratur. Dengan card sort siswa lebih termotivasi dalam belajar sehingga mampu memahami pelajaran dan meningkat kemampuan belajar. Metode penelitian ini adalah kualitatif. Sebagaimana arahan jenis penelitian kualitatif dengan pendekatan fenomenolis. Pendekatan ini, melibatkan peneliti langsung berhubungan atau ikut berproses terhadap objek yang diteliti. Hasil penelitian ini adalah: (1)
\end{abstract}


penerapan Metode Card Sort pada peserta didik kelas IV pada mata pelajaran akidah akhlak di MI Al-Islam Desa Pranggang Kecamatan Plosoklaten Kabupaten Kediri guru memberi kartu indeks yang berisi materi pelajaran akidah akhlak, (2) perubahan kualitas pembelajaran setelah diajar menggunakan metode card sort. Hasil penelitian menunjukkan tes kognitif siswa mendapat nilai rata-rata 84,14 (sangat baik), pada aspek afektif siswa mempunyai rasa keimanan dan ketaqwaan kepada Allah pada psikomotorik siswa melaksanakan ajaran agama Islam dalam kehidupan sehari-hari dengan baik, dan perubahan perilaku sehingga terdapat perubahan sikap dan ketrampilan kea rah lebih baik.

\section{Kata Kunci: Pembelajaran Card Sort, Akidah Akhlak}

\section{Pendahuluan}

Hasil pengamatan pendahuluan di Madrasah ibtidaiyah (MI) Al-Islam Desa Pranggang Kecamatan Plosoklaten Kabupaten Kediri, terdapat beberapa kendala yang dihadapi dalam proses pembelajaran, salah stunya adalah kurangnya pemahaman peserta didik terhadap materi yang diajarkan oleh guru. Kondisi tersebut disebabkan oleh berbagai hal, diantaranya yaitu: 1) Peserta didik kurang memperhatikan materi yang disampaikan karena muncul rasa bosan dengan model pembelajaran yang monoton yaitu lebih banyak didominasi guru dan peserta didik pandai saja, sedangkan peserta didik yang kurang pandai cenderung pasif, 2) cara mengajar guru membosankan, kurang menarik, 3) Dalam proses belajar mengajar selama ini hanya sebatas pada upaya menjadikan anak mampu dan terampil mengerjakan soal-soal yang ada sehingga pembelajaran yang berlangsung kurang

1 Observasi Pribadi, MI Al-Islam Desa Pranggang Kecamatan Plosoklaten Kabupaten Kediri, tanggal 6 Pebruari 2019. bermakna dan terasa membosankan bagi siswa. Hal yang selama ini dirasakan penulis, saat mengajar. Akibatnya, tarjet tujuan pendidikan yang diharapkan tidak bisa terpenuhi. ${ }^{1}$

Selain beberapa kendala di atas, hasil evaluasi guru-guru dan pengawas MI Al-Islam Desa Pranggang Kecamatan Plosoklaten Kabupaten Kediri pada materi asmaul husna, sebelum menggunakan metode card sort, pembelajaran siswa tidak mengalami peningkatan. Akan tetapi setelah penggunaan metode card sort pada mata materi asmaul husna, peningkatan belajar siswa terlihat baik. Hasil pembelajarannya pun dibuktikan dengan peningkatan nilai ujian harian. Secara menyeluruh nilai rata-rata kelas dari pengamatan pendahluan menunjukkan nilai yang kurang menggembirakan atau hanya sebesar $65,6<$ nilai 80 dengan persentase ketuntasan hanya $8 \%<75 \% .^{2}$

Sejatinya, pembelajaran dengan menggunakan metode card sort dapat melalui asas apersepsi, asas motivasi,

2 Ibid., 
asas bekerja sendiri dan asas ulangan yang teratur. Kelebihan lain, metode card sort membuat siswa lebih termotivasi dalam belajar sehingga mampu memahami pelajaran dan meningkat hasil belajar sesuai dengan standar ketuntasan yang diharapkan. Berdasarkan hasil evaluasi pembelajaran asmaul husna tersebut, guru-guru menerapkan metode metode card sort pada materi pelajaran lain, termasuk pelajaran akidah akhlak.

Dalam pembelajaran akidah akhlak, Metode card sort digunakan untuk memberi gambaran secara kongkrit terhadap materi yang disampaikan. Media yang menggunakan potonganpotongan kertas yang disusun secara tepat sehingga siswa mudah meresap materi yang disampaikan.

'Berdasarkan pemikiran di atas, maka pengembangan metode card sort ini berfungsi untuk meningkatkan motivasi belajar peserta didik. Untuk mengetahui tingkat keberhasilan pembelajaran, hasil pengembangan ini diharapkan bisa bermanfaat untuk menguji efektifitas penerapan metode card sort terhadap motivasi belajar peserta didik melalui metode alternatif dan variatif ini. Maka penulis mencoba untuk mengkaji dan meneliti penerapan metode card sort dengan motivasi belajar peserta didik, untuk itu penulis mengangkat judul tesis: " Implementasi Model Pembelajaran Card Sort pada Mata
Pelajaran Akidah Akhlak kelas IV MI AlIslam Desa Pranggang Kecamatan Plosoklaten Kabupaten Kediri ".

\section{Metode Penelitian}

Penelitian ini menggunakan pendekatan kualitatif. Pendekatan kualitatif dipilih karena mampu mendeskripsikan sekaligus memahami makna yang mendasari tingkah laku partisipan, mendiskripsikan latar dan interaksi yang kompleks, eksplorasi untuk mengidentifikasi tipe-tipe informasi, dan mendeskripsikan fenomena". ${ }^{3}$

Penelitian ini diharapkan dapat mendeskripsikan data secara menyeluruh dan utuh mengenai implementasi model pembelajaran card sort pada mata pelajaran akidah akhlak kelas IV MI AlIslam Desa Pranggang Kecamatan Plosoklaten Kabupaten Kediri Secara aplikatif, dalam penelitian ini, peneliti berusaha memahami terlebih dahulu mengenai arti peristiwa dan kaitankaitannya dengan implementasi model pembelajaran card sort dan berusaha masuk dalam dunia konseptual para subjek yang sedang diteliti sedemikian rupa, sehingga mudah dimengerti apa dan bagaimana suatu pengertian yang dikembangkan oleh mereka di sekitar peristiwa dalam kehidupan sehari-hari.

\section{Hasil Dan Pembahasan \\ Penerapan Metode Card Sort}

Berdasarkan hasil wawancara dan observasi pada pembelajaran di kelas IV

\footnotetext{
3 Sanapiah Faisal, (1990), Penelitian Kualitatif: Dasar-Dasar dan Aplikasi, Malang: YA3, hlm. 22.
} 
dengan sebelum guru kelas IV menggunakan metode card short menunjukkan bahwa pembelajaran yang masih menggunakan metode konvensional seperti ceramah dan Tanya jawab saja pembelajaran kurang maksimal karena peserta didik merasa tidak mempunyai motivasi dalam belajar akidah akhlak .

Dalam pembelajaran belum sepenuhnya memahami materi yang disampaikan guru karena guru kurang meksimal dalam memberikan penjelasan terkait dengan materi pelajaran akidah akhlak, guru kurang memberikan acuan pada peserta didik kurang mengefektifitaskan waktu dan guru kurang bisa menguasai kelas sehingga kelas kurang kondusif.

Berdasarkan hasil wawancara dan observasi sebelum penerapan metode card short ini masih banyak peserta didik yang kurang aktif dalam berdiskusi, peserta didik kurang konsentrasi dan kurang memperhatikan pelajaran.

Dalam penggunaan metode selain kesesuaian dari materi seorang guru harus menyesuaikan dengan kondisi dan suasana kelas, jumlah kelas. Demikian juga tingkat intelektual, perbedaan kesanggupan dan kecepatan. Ada enam unsur dasar dari suatu metode, antra lain:

a. Authority, yaitu adanya semacam dari seorang guru, membuat murid yakin dan percaya pada dirinya sendiri. b. Infantilisasi, murid seakan-akan seperti anak kecil yang menerima "authority" dari guru. Ilmu masuk tanpa disadari seperti apa yang dialami oleh seorang anak kecil.

c. Dual komunikasi, yaitu komunikasi verbal dan non verbal yang berupa rangsangan semangat dari keadaan ruangan dan dari kepribadian seorang guru.

d. Intonasi, guru menyajikan materi pelajaran dengan tiga intonasi yang berlainan.

e. Rhythm, yaitu pelajaran membaca dilakukan dengan irama, berhenti sejenak di antara kata-kata dan rasa yang disesuaikan dengan nafas irama dalam.

f. Keadaan Pseudo-Passive, keadaan murid rileks tetapi tidak tidur sambil mendengar irama music. ${ }^{4}$

Jam terakhir pelajaran seringkali menjadi masalah dalam pembelajaran. Melihat peserta didik banyak yang ngantuk pada saat pelajaran jam terahir menjadi tantangan bagi guru untuk bisa menghilangkan situasi tersebut dalam proses belajar. Jika hal tersebut tidak cepat diatasi, maka dapat Akidah Akhlak stikan peserta didik menjadi pasif dan tidak termotivasi dalam belajar. Mungkin inilah salah satu penyebab nilai peserta didik tidak dapat mencapai KKM.

Untuk mengatasi hal tersebut, guru menerapkan metode pembelajaran yang dapat mengajak peserta didik bergerak

4 Azhar, Arsyad, (2012), Bahasa Arab dan Metode Pengajarannya (Beberapa Pokok Pikiran), Makasar: Pustaka Pelajar, hlm.24. 
secara fisik untuk menghindari kantuk, tentu saja tetap fokus pada pembelajaran, sehingga dapat meningkatkan kualitas belajar mereka dengan harapan jika motivasi belajar mereka meningkat maka prestasi mereka juga dapat meningkat. Hal tersebut sejalan dengan pendapat Hisyam Zaini bahwa "Gerakan fisik yang dominan dalam strategi ini dapat membantu mendinamisir kelas yang jenuh dan bosan". 5

Seluruh komponen pendidikan diharapkan dapat membawa kemajuan pendidikan menjadi lebih baik,meskipun kenyataannya masih banyak masalah yang berhubungan dengan kualitas pendidikan,khususnya di Sekolah Dasar diantaranya: penyampaian materi pembe lajaran yang kurang tepat, kurangnya kemampuan peserta didik dalam menyerap pelajaran, guru kurang kreatif dalam memilih dan menggunakan model pembelajaran di kelas.

Untuk mengatasi masalah tersebut di atas, guru kelas IV yang mengajar mata pelajaran akidah akhlak di Al-Islam bisa menggunakan model pembelajaranyang bervariasi sesuai dengan materi dankondisi peserta didik di sekolah pada semua mata pelajaran khususnya pelajaran Ilmu Pengetahuan Alam dalam setiap kegiatan belajar mengajar, karena mata pelajaran akidah akhlak bersentuhan langsung dengan alam sekitar dan kehidupan sehari-hari siswa.
Efektif

tidaknya metode pembelajaran memang tidak terlepas dari berbagai faktor yang mempengaruhinya. Dalam hal ini dibutuhkan guru kreatif yang dapat membuat pembelajaran menjadi lebih menarik dan disukai oleh peserta didik. Suasana kelas perlu direncanakan dan dibangun sedemikian rupa dengan menggunakan model pembelajaran yang tepat agar peserta didik dapat memperoleh kesempatan untuk berinteraksi satu sama lain sehingga pada gilirannya dapat diperoleh prestasi belajar yang optimal.

Model pembelajaran yang perlu diterapkan di sekolah untuk pelajaran akidah akhlak misalnya, model pembelajaran card short. Model pembelajaran ini termasuk dalam kelompok model pembelajaran aktif. Penggunaan atau penerapan model pembelajaran ini dalam kegiatan belajar mengajar di kelas mata pelajaran akidah akhlak Madrasah Ibtidaiyah dapat meningkatkan motivasi belajar peserta didik pada khususnya dan meningkatkan kualitas pendidikan pada umumnya. Dan Penggunaan model pembelajaran card short ini akan memberikan suasana yang menyenangkan, saling bekerjasama dalam kelompok.

Beberapa keunggulan model pembelajaran card short adalah: 1 . memungkinkan peserta didik untuk bekerja sendiri dan bekerjasama dengan orang lain, 2. mengoptimalkan partisipasi peserta didik pada orang lain. Model

\footnotetext{
5 Hisyam, Zaini, (2012), Strategi Pembelajaran Aktif di Perguran Tinggi, Yogyakarta:
} PT.CTSD, hlm.30 
pembelajaran card short adalah strategi pembelajaran yang sederhana tetapi sangat bermanfaat.

Pembelajaran yang menggunakan metode card short mengikuti langkahlangkah, peserta didik berfikir terhadap masalah yang diajukan oleh guru kepada peserta didik di kelas, peserta didik diminta untuk memikirkan sebuah jawaban dari mereka sendiri, lalu peserta didik berpasangan dengan pasangannya untuk berdiskusi tentang hasil pemikiranya terhadap masalah yang diajukan oleh guru hingga tercapai sebuah kesepakatan terhadap jawaban, dan akhirnya guru meminta peserta didik berbagi hasil untuk seluruh kelas.

Berdasarkan paparan data bahwa langkah-langkah yang dilakukan guru kelas IV dalam menerapkan metode card short adalah sebagai berikut:

a. Langkah pertama, guru membagikan selembar kartu kepada setiap siswa dan pada kartu tersebut telah dituliskan suatu materi. Kartu tersebut terdiri dari kartu perhuruf.

b. Langkah kedua, siswa diminta untuk mencari teman (pemegang kartu) yang sesuai dengan masalah yang ada pada kartunya untuk satu kelompok.

c. Langkah ketiga, siswa akan berkelompok dalam satu mufrodat atau masalah masing-masing.

d. Langkah keempat, siswa diminta untuk menempelkan di papan tulis bahasan yang ada dalam kartu tersebut berdasarkan urutanurutan bahasannya yang dipegang kelompok tersebut.

e. Langkah kelima, seorang siswa pemegang kartu dari masingmasing kelompok untuk menjelaskan dan sekaligus mengecek kebenaran urutan per-huruf dalam satu mufrodat.

f. Langkah keenam, bagi siswa yang salah mencari kelompok sesuai bahasan atau materi pelajaran tersebut, diberi hukuman dengan mencari judul bahasan atau materi yang sesuai dengan kartu yang dipegang.

g. Langkah ketujuh, guru memberikan komentar atau penjelasan dari permaianan tersebut.

Hal tersebut sejalan dengan pendapat Ismail SM langkah-langkah yang dilakukan dalam metode Card Sort adalah :

a. Guru menyiapkan kartu berisi tentang materi pokok sesuai SK (Standar Kompetensi) atau KD (Kompetensi Dasar) mata pelajaran yang diajarkan

b. Seluruh kartu diacak/dikocok agar campur

c. Bagikan kartu kepada murid dan pastikan masing-masing memperoleh satu (boleh dua)

d. Perintahkan setiap murid bergerak mencari kartu induknya dengan mencocokkan kepada kawan sekelasnya

e. Setelah kartu induk beserta seluruh kartu rinciannya ketemu, perintahkan masing-masing membentuk kelompok dan menempelkan hasilnya di papan secara urut 
f. Lakukan koreksi bersama setelah semua kelompok menempelkan hasilnya

g. Mintalah salah satu pertanggungjawaban kelompok untuk menjelaskan hasil sortir kartunya, kemudian mintalah komentar dari kelompok lainnya

h. Berikan aspirasi setiap hasil kerja murid. ${ }^{6}$

Senada dengan pendapat diatas, adalah Hartono juga menjelaskan tentang langkah-langkah yang dilakukan dalam metode Card Sort adalah :

a. Masing-masing siswa diberikan kartu indek yang berisi materi pelajaran. Kartu indek dibuat berpasangan berdasarkan definisi, kategori/kelompok, misalnya kartu yang berisi aliran empiris dengan kartu pendidikan ditentukan oleh lingkungan dll. Makin banyak siswa makin banyak pula pasangan kartunya.

b. Guru menunjuk salah satu siswa yang memegang kartu, siswa yang lain diminta berpasangan dengan siswa tersebut bila merasa kartu yang dipegangnya memiliki kesamaan definisi atau kategori.

c. Agar situasinya agak seru dapat diberikan hukuman bagi siswa yang melakuan kesalahan. Jenis hukuman dibuat atas kesepakatan bersama.

d. Guru dapat membuat catatan penting di papan tulis pada saat prosesi terjadi. $^{7}$

Metode Card Sort merupakan sebuah strategi pembelajaran yang membantu siswa untuk mendapat

6 Ismail SM, (2018), Strategi Pembelajaran Agama Islam Berbasis PAIKEM, Bandung: Remaja Rosda Karya, hlm. 27 pengetahuan, keterampilan, dan sikap secara aktif serta menjadikan belajar tidak terlupakan. Kedua metode ini berpusat pada peserta didik, sehingga menuntut siswa untuk lebih aktif dan guru sebagai fasilitator saja. Metode pembelajaran Card Sort bisa digunakan sebagai metode alternatife yang dirasa lebih bisa memahami karakteristik belajar peserta didik yang berbeda-beda. Diantaranya ada peserta didik yang lebih senang membaca, diskusi, atau praktek langsung. Agar dapat membantu peserta didik belajar secara maksimal, kesenangan dalam belajar itu perlu diperhatikan, salah satunya dengan menggunakan variasi metode pembelajaran yang beragam dengan melibatkan indra 'belajar yang banyak. Siswa akan lebih cepat memahami pelajaran apabila siswa dilibatkan secara aktif baik mental maupun fisik.

Dalam hal ini guru dituntut untuk dapat menggunakan metode yang tepat serta mengajak siswa untuk aktif bergerak sehingga dapat membuat siswa merasa senang dan pelajaran tidak terasa membosankan. Metode Card Sort merupakan metode yang baru, yang akhir-akhir ini mulai digunakan di semua mata pelajaran yang ada di sekolah. Metode ini lebih bervariatif dibanding dengan model pembelajaran yang terdahulu.

Untuk menjembatani berbagai tipe dalam belajar siswa, guru harus pandai

7 Hartono, (2011), Strategi Pembelajaran Active Learning, Bandung: Rajawali Press, hlm. 13 
memenfaatkan strategi atau pendekatan pembelajaran agar siswa melaksanakan kegiatan belajar dengan optimal. Guru harus arif dan mengetahui, bahwa ada diantara siswa yang lebih senang membaca, ada yang lebih senang berdiskusi dan ada juga yang senang praktek langsung. Sehingga untuk membantu siswa dalam belajar secara maksimal, kesenangan dalam belajar perlu diperhatikan, salah satunya dengan menggunakan variasi strategi pembelajaran yang beragam yang melibatkan indra belajar yang banyak, salah satunya dengan menggunakan strategi Card Sort.

Dalam fakta di lapangan ternyata strategi Card Sort bila diterapkan dalam pembelajaran pada mata pelajaran akidah akhlak di kelas IV bisa digunakan sebagai strategi alternatif yang dirasa lebih bisa memahami karakteristik siswa. Karakteristik yang dimaksud disini adalah siswa lebih menyukai belajar sambil bermain, maksudnya dalam proses belajar mengajar, guru harus membuat siswa tertarik dan senang terhadap materi yang disampaikan, sehingga nantinya tujuan pembelajaran dapat dicapai.

Selama proses card short terjadi, suasana kelas sangat dinamis dan terdengar gaduh tetapi masih dalam koridor belajar. Peserta didik yang pada pertemuan sebelumnya mengantuk kini tidak lagi, karena mereka harus berkonsentrasi menerima lemparan soal dan menjawabnya. Peserta didik aktif dan semangat dalam membahas dan sehingga dapat meningkatkan hasil belajar peserta didik sesuai dengan yang diharapkan untuk dapat mencapai KKM.

\section{Perubahan Hasil Peserta Didik Setelah Diajar Menggunakan Metode Card Sort}

Dalam kegiatan pendidikan, proses pembelajaran merupakan suatu aktifitas yang tidak dapat ditinggalkan. Bahwa pembelajaran sangat penting dan perlu, karena sebagian besar sumber ilmu pengetahuan dapat diterima dalam proses bembelajaran. Dalam lingkungan pendidikan seperti MI Al-Islam Pranggang Plosoklaten Kediri ciri khas pendidikan Islam. Oleh karena itu sangat diperlukan pembelajaran yang bercirikan agama Islam.

Metode yang digunakan di MI AlIslam Pranggang Plosoklaten Kediri dalam pembelajaran akidah akhlak menggunakan metode yang berfariasi dan sesuai dengan materi, sehingga peserta didik mudah untuk menangkap pelajaran, tidak merasa jenuh dan bosan.

Hal tersebut seperti yang diungkapkan oleh Newman dan Logan. Menurut Newman dan Logan, strategi dasar arti meliputi empat masalah, yaitu:

a. Mengidentifikasi dan penetapan spesifikasi dan kualifikasi hasil yang harus dicapai dan menjadi sasaran usaha tersebut dengan mempertimbangkan aspirasi masyarakat yang dipelukan.

b. Pertimbangan dan pemilihan pendekatan utama yang ampuh untuk mencapai sasaran 
c. Pertimbangan dan penetapan langkah-langkah yang ditempuh sejak awal sampai akhir

d. Pertimbangan dan penetapan untuk tolak ukut dan ukutan baku yang akan digunakan untuk menilai keberhasilan usaha yang dilakukan. ${ }^{8}$

Dari beberapa penjelasan metode card short di atas maka dapat diambil kesimpulan bahwa metode kegiatan belajar yang telah dirumuskan dan direncanakan harus sesuai dengan tujuan sehingga hasil yang diperoleh bisa efektif dan efisien tidak mengecewakan anak didik.

Setiap orang harus melaksanakan sesuatu hal pasti ada tujuannya, begitu juga dengan metode belajar mengajar yang mempunyai pengertian kegiatan yang dilakukan guru dan peserta didik yang terikat oleh suatu tujuan yang terarah. Karena meneruskan tujuan merupakan aspek yang penting yang harus diperhatikan dalam mengajar.

Bahwasanya tujuan metode card short diharapkan agar para pendidik dan calon pendidik mampu melaksanakan serta mengatasi program permasalahan pendidikan dan pengajaran, selain itu para pendidik dan calon pendidik memiliki wawasan yang utuh, lancar, terarah, sistematis dan efektif.

Guru kelas IV yang mengajar mata pelajaran akidah akhlak juga berusaha menerapkan metode pembelajaran card short yang dimodifikasi dan dikembang- kan. Misalkan metode pembelajaran card short yang dimodifikasi dengan metode praktek.

Sebagai salah satu unsur pelaksanaan metode pembelajaran adalah tehnik penyajian bahan pelajaran atau biasa disebut dengan metode mengajar. Fungsi metode ini adalah alat untuk mencapai tujuan pembelajaran. Berbagai macam metode yang digunakan dalam interaksi belajar mengajar.

Dalam menerapkan metode pembelajaran berbagai macam metode mengajar antara lain adalah metode dongeng, metode eksperimental, metode demonstrasi, dan metode praktek, telah diterapkan di madrasah ini, metodemetode yang diterapkan di MI Al-Islam Pranggang Plosoklaten Kediri telah disesuakikan dengan materi. Dan kemungkinan besar anak-anak akan tertarik dan ingn mencoba untuk mempraktekkan di rumah dengan cara dan dengan inisiatif sendiri.

Agar peserta didik merasa tidak jenuh dalam belajar, tidak merasa tertekan atau bahkan stres, kepala sekolah selalu menyarankan kepada guru akidah akhlak untuk menggunakan strategi mengajar yang bervariasi, tidak monoton seperti ceramah dan ceramah saja. Kepala madrasah yang juga sebagai guru akidah akhlak kelas IV juga tidak jemu-jemunya memperbaiki dan mengembangkan metode mengajarnya, salah satu kiat yang saya sarankan

8 Ahmadi, Abu dan Joko Triprasetyo, (2010), Strategi Belajar Mengajar, Bandung: CV, Pustaka Setia, hlm. 11-12 
supaya murid mersa gembira di kelas, guru akidah akhlak kelas IV untuk tidak pasang wajah cemberut yang membuat peserta didik takut tetapi tersenyum sehingga peserta didik dapat merasa enjoy mengikuti jalanya pelajaran

Guru itu memang harus kreatif, ini merupakan tanggung jawab profesi yang diembannya, guru harus bisa menggunakan dan mengembangkan metode card short sesuai dengan kondisi yang ada. Seperti di MI Al-Islam Pranggang Plosoklaten Kediri ini, seluruh kegiatan pembelajaran harus menstimulasi ketiga ranah afektif, kognitif dan piskomotorik dengan menggunakan berbagai pendekatan belajar atau metode belajar. Sekarang belajar tidak boleh lagi hanya terpaku pada pembahasan-pembahasan konsep dan teori belaka. Setiap pokok bahasan harus berupaya menarik minat anak terhadap pokok bahasan tersebut, serta membimbing mereka untuk masuk pada dunia aplikasinya, sehingga juga akan menumbuhkan semangat dan motivasi belajar yang tinggi, karena suasana menyenangkan dan menantang akan selalu mereka dapatkan.

Kebanyakan guru berbicara sekitar 100-200 kata per menit, sementara anak didik hanya mampu mendengarkan 50100 kata per menitnya (setengah dari apa yang dikemukakan guru), karena peserta didik mendengarkan pembicaraan guru sambil berpikir. ${ }^{9}$

Penambahan visual pada proses pembelajaran dapat menaikkan ingatan sampai $171 \%$ dari ingatan semula.
Dengan penambahan visual di samping auditori dalam pembelajaran kesan yang masuk dalam diri anak didik semakin kuat sehingga dapat bertahan lebih lama dibandingkan dengan hanya menggunakan audio (pendengaran) saja. Hal ini disebabkan karena fungsi sensasi perhatian yang dimiliki peserta didik saling menguatkan, apa yang didengar dikuatkan oleh penglihatan (visual), dan apa yang dilihat dikuatkan oleh audio (pendengaran). Dalam arti kata pada pembelajaran seperti ini sudah diikuti oleh reinforcement yang sangat membantu bagi pemahaman anak didik terhadap materi pembelajaran.

Dengan menggunakan metode card sort terbukti telah terjadi komunikasi yang komunikatif, siswa mudah memahami maksud dari materi yang disampaikan guru dan sebaliknya guru mudah mentransfer ilmu pengetahuan kepada siswa, melalui media ini guru dapat membuat contoh-contoh, interpretasi-interpretasi sehingga siswa mendapat kesamaan arti sesama mereka.

Setelah menggunakan metode card sort hasil belajar siswa dapat meningkat, hal ini dapat diketahui dari peningkatan kompetensinya . Pemilihan metode card sort ini oleh guru akidah akhlak juga didasarkan pada landasan filosofis pemikiran Islam dalam memandang alam semesta, manusia dan hakekat kehidupannya. Menurut pandangan Islam, pada hakekatnya hidup manusia sebagai hamba Allah membawa konskuensi untuk senantiasa taat kepada syariat 
Allah SWT. Oleh karena itu, pendidikan harus diarahkan untuk membentuk kepribadian Islam yang tangguh, yaitu manusia yang memahami hakekat hidupnya dan mampu mewujudkannya.

Dalam fakta temuan di lapangan pada pelajarna akidah akhlak ini guru akidah akhlak berusaha keras dalam membina akidah siswa, Salah satu usaha yang dilakukan para guru akidah akhlak adalah dengan menambah bahan ajar berupa buku-buku pegangan siswa pada mata pelajaran akidah akhlak.

Perubahan hasil belajar siswa pada mata pelajaran akidah akhlak ada yang secara langsung dan tidak langsung. Secara langsung yaitu cara-cara tertentu yang ditujukan langsung kepada pembentukan akhlaq, antara lain: tauladan, nasehat, latihan, dan hadiah. Sementara nilai akhlak yang tidak langsung yaitu cara-cara tertentu yang bersifat pencegahan dan penekanan, antara lain : koreksi dan pengawasan, larangan, hukuman dan sebagainya. Dari bentuk-bentuk pendidikan akhlaq ini diharapkan nilai-nilai akhlak dapat menjadi kepribadian anak didik, artinya bukan hanya bersifat formal dalam ucapan dan teori belaka, akan tetapi sampai pada tingkat pelaksanaan dalam kehidupan.

Beberapa nilai atau hikmah yang dapat diraih berdasarkan ajara-ajaran amaliah Islam (akhlaq) antara lain: alamanah (berlaku jujur), al-rahman (kasih sayang), al-haya' (sifat malu), al-shidq (berlaku benar), al-syaja'ah (berani), qana'ah atau zuhud, al-ta'awun (tolongmenolong) dan lain-lain.

Menurut Ibnu Miskawaih Manusia, mempunyai tiga potensi, Yaitu potensi bernafsu (an-nafs al-bahimiyyah), potensi berani (an-nafs as-subuiyyat) dan potensi berfikir (an-nas an-nathiqiyah). Potensi bernafsu dan potensi berani berasal dari unsur materi sehingga akan hancur pada suatu saat, sedangkan potensi berfikir berasal dari ruh Tuhan sehingga bersifat kekal. ${ }^{10}$

Perubahan hasil belajar pada mata pelajaran akidah akhlak inilah yang harus ditanamkan kepada siswa melalui kegiatan pembelajaran bukan sekedar akhlaqul karimah, melainkan akhlaq madzmumah juga harus di sampaikan dan diajarkan kepada anak. Bila akhlaq yang buruk itu tidak di sampaikan kepada anak maka anak akan melakukan perbuatan yang tidak sesuai dan melanggar etika yang ada di masyarakat itu.

\section{Kesimpulan}

a. Penerapan Metode Card Sort pada peserta didik kelas IV pada mata pelajaran akidah akhlak di MI Al-Islam Desa Pranggang Kecamatan Plosoklaten Kabupaten Kediri adalah guru memberi kartu indeks yang berisi materi pelajaran akidah akhlak. Kartu indeks dibuat berpasangan berdasarkan definisi, kategori/kelompok. 
Makin banyak peserta didik makin banyak pula pasangan kartunya.

b. Perubahan hasil belajar peserta didik setelah diajar menggunakan metode card sort kelas IV pada mata pelajaran akidah akhlak di MI Al-Islam Desa Pranggang Kecamatan Plosoklaten Kabupaten Kediri adalah hasil tes kognitif siswa mendapat nilai rata-rata 84,14, pada aspek afektif siswa mempunyai rasa keimanan dan ketaqwaan kepada Allah pada psikomotorik siswa melaksanakan ajaran agama Islam dalam kehidupan sehari-hari sehingga dapat membentuk pengetahuan, sikap dan ketrampilan seluruh peserta didik di sini sesuai yang ditargetkan, yakni memadukan secara utuh ranah kognitif, afegtif dan psikomotorik dalam seluruh aktivitas belajar. Serta respon siswa terhadap motode belajaran ini sangat baik karena siswa menyukai metode belajar card sort.

\section{Daftar Pustaka}

Ahmadi, Abu dan Joko Triprasetyo, (2010), Strategi Belajar Mengajar, Bandung: CV, Pustaka Setia

Azhar, Arsyad, (2012), Bahasa Arab dan Metode Pengajarannya (Beberapa Pokok Pikiran), Makasar: Pustaka Pelajar

Faisal, Sanapiah (1990), Penelitian Kualitatif: Dasar-Dasar dan Aplikasi, Malang: YA3

Hartono, (2011), Strategi Pembelajaran Active Learning, Bandung: Rajawali Press

Hisyam, Zaini, (2012), Strategi Pembelajaran Aktif di Perguran Tinggi,
Ismail SM, (2018), Strategi Pembelajaran Agama Islam Berbasis PAIKEM, Bandung: Remaja Rosda Karya.

Nata, Abuddin (2016), Pemikiran Para Tokoh Pendidikan Islam, Kajian Filsafat Pendidikan Islam, Jakarta : Raja Grafindo Persada

Silberman, Melvin L. (2011), Active Learning 101 Cara Belajar Siswa Aktif, Bandung: Nusamedia, edisi revisi

Yasin, A. Fatah (2008). Dimensi-dimensi Pendidikan Islam, Malang: UIN PRESS.

Zaini, Hisyam dkk, (2014) Strategi Pembelajaran Aktif, Yogyakarta: CTSD 